\title{
Utilization of non-conventional fibre yielding crops in Karnataka
}

JYOTI V. VASTRAD, RAJASHRI KOTUR AND SHAMEEMBANU A. BYADGI

Received : 19.03.2015; Revised : 18.08.2015; Accepted : 14.09.2015

See end of the Paper for authors' affiliation

Correspondence to :

JYOTI V. VASTRAD

All India Co-ordinated

Research Project on Clothing

and Textiles, College of Rural

Home Science, University of

Agricultural Sciences,

DHARWAD (KARNATAKA)

INDIA

Email : jyotivastrad@gmail.com
-ABSTRACT : Natural fibres have wide range of application in the field of textiles, particularly in the light of recent global inclination towards eco-friendly textiles. User friendly fabrics are gradually gaining importance and consumers are continuously looking for bio-degradable and eco-friendly textiles to preserve their natural environment, flora and fauna. The present study was carried out to know the availability and utilization of non-conventional fibres in various agroclimatic zones of Karnataka state. The results revealed that respondents utilized mesta and agave fibres for making cordages, ropes for home or farm requirements and also sell the cordages. The farmers lose market price significantly due to the reason that they do not undertake proper cleaning and grading of the produce before sales, which is also one of the reasons for low price. Although pineapple, arecanut and coconut are extensively grown in zone -10 , coconut husk was transported to nearby towns and co-operative societies for fibre extraction. However, no reports of pineapple leaf fibre and arecanut fibre extraction was found and are thrown as agricultural waste due to the improper knowledge of fibre qualities, and lack of facilities for fibre extraction. Hence, there is need to study the fibre qualities and produce variegated products for commercialazization.

- KEY WORDS : Biodegradable, Eco-friendly, Fibre extraction, Non-conventional fibres, Utilization

- HOW TO CITE THIS PAPER : Vastrad, Jyoti V., Kotur, Rajashri and Byadgi, Shameembanu A. (2015). Utilization of non-conventional fibre yielding crops in Karnataka. Internat. J. Agric. Engg., 8(2) : 198-205. 